oraz pod jego opieka alumni wydają „Perłę Misji”, kwartalnik poświęcony szeroko pojętym sprawom Ziemi św. Oprócz aktualności wydobywa on na światło dzienne na ogół nieznane polskie ślady w Ojczyźnie Chrystusa. Pismo dociera do prawie wszystkich domów braci mniejszych w Polsce.

Zakliczyn n. Dunajcem

O. ANZELM SZTEINKE OFM

Ks. Jerzy Chmiel

\title{
PRAWO W NOWYM TESTAMENCIE. SYMPOZJUM BIBLIJNE W BRIXEN 1985
}

W dwujęzycznej miejscowości Bressanone/Brixen, położonej we włoskich Dolomitach (według nomenklatury włoskiej) a w poludniowym Tyrolu (według nomenklatury niemieckiej) miało miejsce w marcu $1985 \mathrm{r}$. odbywające się co dwa lata sympozjum nowotestamentalne egzegetów języka niemieckiego (Tagung der deutschsprachigen katholischen Neutestamentler). Tematem obrad było „Prawo w Nowym Testamencie”. Warto choćby $\mathrm{w}$ pobieżnym skrócie przekazać ważniejsze myśli z referatów tam wygłoszonych i z dyskusji po nich toczonych.

K.-H. Müller (Würzburg) mówil nt. „Prawo i jego wypełnienie we Wczesnojudaistycznym przekazie”. W pierwszej części referatu M. zestawił pojęcie prawa i Tory. Wykorzystal przy tym mało znane aramejskie papirusy z Elefantyny (3 dokumenty umowy małżeńskiej), jak również kumrański Zwój Swiątynny. Tora i prawo nie były to pojęcia tożsame. Miszna nie była dedukcją z Tory. Autor przeprowadził analize halaki judaistycznej, posługując się obficie literaturą apokryficzną i filońską. Druga część referatu dotyczyła wypełnienia prawa.

Z dyskusji warto odnotować głos H. Schürmanna, iż nie należy uważać rauczania Jezusa za formę halaki judaistycznej. W Jezusowym wykładzie Tory odczuwa się autorytet.

G. Da utzenberg (Giessen) miał referat nt. „Wypełnienie prawa i jego krytyka w tradycji Jezusa". Paweł nie widział konfliktu Jezusa z Torą (por. Ga 4, 4; Rz 15, 8); zwłaszcza godne uwagi jest stwierdzenie diakonos peritomēs - "sługa obrzezania" (lepiej niż "obrzezanych", jak w BT). D. proponuje nowe rozumienie peritomé: Jezus jest związany z tradycją synajską Przymierza i Tory (por. perf. gegenēsthai dla skutku trwającego!). W drugiej części referatu D. zajął się krytyką prawa u Mk stwierdzając, że opozycja przeciw prawu u Mk jest inna niż wolność od prawa u Pawła. Część trzecia wystąpienia D. obejmowała rozumienie prawa w logiach (Logienquelle).

Koreferat wygłosił P. Fi e d l er (Fryburg).

W dyskusji F. Mussner zapytywal, czy teologia Pawla jest antyjudaistyczna? Należy pamiętać, że normalny żyd żył nie tylko z prawa; jest jeszcze wpływ mądrości (P.-G. Müller). W Antiochii, w ośrodku hellenistycznym, żydzi żyli ściśle według Tory. H. Schürmann zwrócił uwagę, że w przepisach pokarmowych mamy do czynienia nie tylko z przepisami faryzejskimi, lecz także ze zwyczajami ogólnożydowskimi. Ważna to rzecz w dojściu do Jezusa historycznego. 
F. M ussner (Passau) zajął się w swym referacie problemem ,Czy wypełnianie prawa przez żydów należy określić jako formalizm i uczynki pobożności (Leistungsfrömmigkeit)?" Tora miała wielorakie konotacje: z przymierzem, z mądrością (w Pwt 4, 6 mamy do czynienia ze spirytualizacją Tory), z łaską, z objawieniem. Dlaczego przyszło do konfliktu pomiędzy Jezusem a rabinami (jak zastanawiał się J. Neussner na spotkaniu w Monachijskiej Akademii Teologicznej)? Ponieważ bez Tory nie ma judaizmu.

Od Bultmanna - zaznaczono w dyskusji - mamy obraz judaizmu perwersyjnego. Nie należy mówić o chrystologii i Torze w kategoriach antytetycznych.

„Rozumienie prawa u Pawła" przedstawił J. Lambrecht SI. Omówił najpierw rozumienie prawa w przedpawłowej tradycji, w nauczaniu Jezusa i w pierwotnym Kościele. Były dwa geograficzne bieguny: Jerozolima i Antiochia. Następnie L. zajął się rozpatrywaniem opinii egzegetów co do rozumienia prawa przez Pawła. Niektórzy twierdzą, że z początku Paweł nie był tak przeciwny prawu, dopiero potem występował przeciwko konserwatystom tak radykalnie. Paweł jest przeciwko prawu jako gwarancji ocalenia Izraela. Chodzi tu o trzy grupy przepisów: obrzezanie, przepisy pokarmowe, święcenie szabatu. W końcu L. omówił rozumienie prawa u Pawła wg Ga 3, 10-14, dokonując wnikliwej analizy.

Podczas dyskusji R. Schnackenburg przypomnial znane adagium teologiczne: „Bóg stworzył nas bez nas, ale nas nie zbawi bez nas".

J. Be utler SI (Sankt Georgen, Frankfurt) zajął się zagadnieniem: „Główne przykazanie w Ewangelii Janowej (i w innych pismach Janowych)". Punktem wyjścia było podwójne prawo miłości z Pwt 6, 4, tak jak występuje u Mk i Mt. W $J$ są pewne przepracowania i niejasności. Np. crux interpretum w J 5, 42: prelegent opowiedział się za gen. subiectıvus i obiectivus. W Corpus Ioanneum następuje zasadnicza interioryzacja prawa - jest to prawo miłości.

Oprócz sesji plenarnych odbywały się prace w grupach (seminariach), bardzo ciekawe i owocne ze względu na szerszą możliwość dyskusji i wymiany poglądów. Były cztery grupy seminaryjne:

1. Jezus i prawo wg Ewangelii Mateusza; 2. Spór o prawo w Dziejach Apostolskich; 3. Wiara i prawo u Pawła; 4. Prawo w Liście Jakuba (w ramach wczesnego chrześcijaństwa). W czasie dyskusji końcowej złożono sprawozdania z prac w grupach. Seminarium I skoncentrowało się na trzech zágadnieniach: a) antytezy u Mt, b) prawo rytualne, c) prawo a Ewangelia. Seminarium II objęło swym zakresem: a) konflikt ze Szczepanem, b) widzenie Piotra, c) nawrócenie Korneliusza, d) mowę Pawła w Antiochii Pizydyjskiej. Seminarium III zwróciło uwagę na teksty w Rz i Ga. Seminarium IV analizowało Jk od strony pól sematycznych, zwracając uwagę na ukierunkowanie teocentrycznego prawa i na aspekty mądrościowe. Pareneza jest bardziej radykalna. Nie ma zależności literackiej Jk od Pawła.

$\mathrm{W}$ dyskusji ponadto zwracano uwage na konieczność ścisłego (tzn. naukowego) stosowania reguł hermeneutyki w egzegezie. A. Vögtle (Fryburg) powiedział: "hermeneutyczne znaczenie Objawienia jest jego znaczeniem historycznym".

Materiały sympozjum mają się ukazać w wyd. Herdera we Fryburgu: K. Kertelge (Hg.): Das Gesetz im Neuen Testament (Quaestiones disputate B. 108), 1986 (stron ok. 272).

$\mathrm{Na}$ zakończenie niniejszego sprawozdania warto jeszcze zasygnalizować polonica w Bressanone/Brixen. W kościele seminaryjnym znajduje się obraz ołtarzowy św. Jana Kantego ufundowany tam w rok po kanonizacji świętego (1767). W miejscowym muzeum znajdują się obrazy sygnowane: Martin Theoph. Polacus.

Kraków 